\title{
Is Sparing the Deep Lobes of Parotid Gland Necessary on Intensity Modulated Radion Therapy of Head and Neck Cancers?
}

\author{
Eren CETIN ${ }^{1}$, Aysen S. OZTURK ${ }^{2}$, Haluk ORHUN ${ }^{2}$, Duygu BAYCAN ${ }^{2}$, Ali DOGAN ${ }^{3}$ \\ ' Gazi University Faculty of Medicine, Department of Radiation Oncology \\ ${ }^{2}$ Medicana International Ankara Hospital, Division of Radiation Oncology \\ ${ }^{3}$ Hacettepe University Faculty of Medicine, Department of Radiation Oncology, Ankara, TURKEY
}

\begin{abstract}
RT to the lymphatics of the neck is an essential component in squamous cell cancers of the head and neck (SCCHN). Radiation induced mouth dryness, thickening of saliva and taste alteration affects nutrition and performance status of the patients. Protection of parotid glands from radiation is an important task during RT planning. Contemporary methods such as intensity modulated radiation therapy (IMRT) ease the protection of parotid glands. Most of the recurrences are seen close to the spared deep lobe of parotid glands. Exclusion of the deep lobes for sparing with dosimetric analysis has not been studied in the literature. In this study, we evaluated treatment plannings of 13 patients with SCCHN. As a dosimetric analysis, we compared the applied IMRT and the virtual IMRT without delineation of deep lobe of parotid glands. The dose for lymphatic region was prescribed as 50-54 Gy. Superficial and/or deep lobe of parotid gland was constrained as $26 \mathrm{~Gy}$.

Without definition of deep lobe, the radiation for dose lymphatic region planning target volume (PTV) was achieved without any dose change in the primary or high risk regions. With definition of deep lobe, the mean dose of lymphatic region PTV (not less than 95\%) decreased by 5.8\% (2.9-3.1 Gy). In conclusion, exclusion of sparing of deep lobe of parotid gland prevents decrease of radiation dose in the lymphatic region. It would be a treatment rationale to avoid the dose drop in the metastatic side of the neck region or the site of high risk for recurrence next to the parotid gland.
\end{abstract}

Keywords: Radiation therapy, Parotid, Intensity modulated radiation therapy

\section{ÖZET}

\section{Baş-Boyun Kanserli Hastalarının YART Tedavisinde Parotis Bezinin ve Derin Loblarının Korunması Gerekli mi?}

Baş boyun kanser tanılı hastaların çoğunda, boyun lenfatik bölgesine radyoterapi uygulanır. Radyasyona bağı ağız kuruluğu, tükrük kıvamında arış̧ ve tat almada değişme hastaların beslenmelerini ve hatta performanslarını etkilemektedir. Radyoterapi planlamasında radyoduyarlı organ olan parotis bezlerinin korunması önemlidir ve son yıllarda yoğunluk ayarlı radyoterapi (YART) bu işi kolaylaştırmıştır. Radyoterapi sonrası boyun bölgesi rekürrenslerinin önemli bir kısmı parotis bezine yakın bölgede görülmektedir. Lenfatik bölgeye yakın olan derin lobun tanımlanmadan YART doz analizi ve dokümantasyonu yapılmamışıı. Bu çalışmada, baş boyun kanserli 13 hastanın derin lob tanımı ve tanımsız YART tedavi planlarını dozimetrik analiz olarak değerlendirdik. Lenfatik bölge doz tanımı 50-54 Gy ve parotis bezi doz tanımı (yüzeyel ve/veya derin loblar) 26 Gy olarak planlandı. Derin lob tanımlanmadığında, primer bölge ve yüksek riskli bölgelerde doz değişimi olmaksızın lenfatik bölge radyasyon dozu oluşturulmuştur. Derin lob tanımlandığında ise, lenfatik bölgenin özellikle parotis derin lob yakınında olan bölgede \%5.8 (2.9-3.1 Gy) doz düşmesi bulundu. Sonuç olarak, parotis bezi derin lobunu tanımlamadan yapılan tedavi planında, boyun lenfatik bölge radyoterapi dozunun düşmesinin engellenebilir. Boyun lenfatik bölge metastazlı taraf veya parotis bezine yakın yüksek riskli bölgede doz düşmelerini engellemede tedavi rasyoneli olarak değerlendirilebilir.

Anahtar Kelimeler: Radyoterapi, Parotis, YART 


\section{INTRODUCTION}

Radiotherapy (RT) to the neck lymphatics is frequently applied in squamous cell cancers of the head and neck (SCCHN). The major salivary glands of the mouth are parotid glands which produce $65 \%$ of total oral salivary output.' They are radiosensitive organs at risk for radiation of upper neck or pharyngeal cancers. Protecting parotid gland during RT is important to avoid hyposalivation and xerostomia for optimum quality of life and nutrition. ${ }^{2.3}$ Xerostomia may occur at doses above 26 Gy for parotid glands. ${ }^{4}$ Sparing the parotid glands could be achieved by using intensity modulated RT (IMRT). Furthermore, the deep lobe of parotid gland which is very close to the target lymphatic region to be irradiated causes a series of clinical problems. After definitive IMRT for SCCHN patients, the recurrences are seen in the region of spared parotid gland. ${ }^{5,6}$ Dose escalation is recommended for high risk lymphatic regions at which the majority of local recurrences occur. ${ }^{7.8}$ Nevertheless, the exclusion or inclusion of the deep lobe for IMRT planning is not well documented in terms of its effects on radiation dose of the neighboring lymphatic regions.

In this study, we evaluated treatment plannings of 13 patients of SCCHN. As a dosimetric analysis, we compared the applied IMRT and the virtual IMRT without definition of deep lobe of parotid glands.

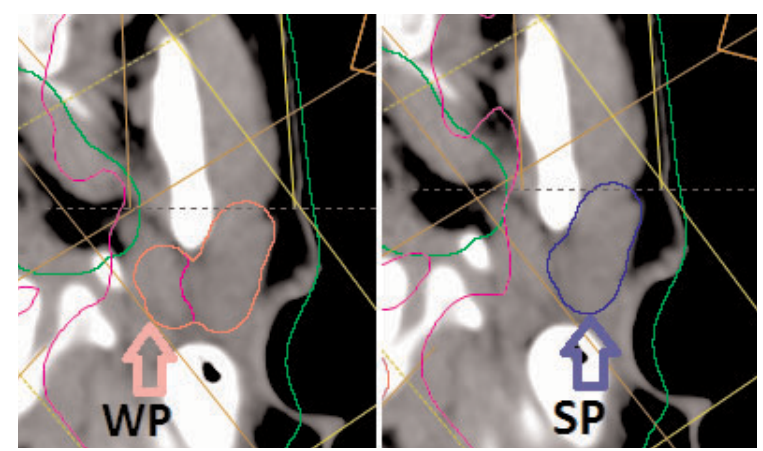

Figure 1. Whole parotid gland and superficial lobe delineation

WP: Whole parotid gland delineation (pink line) $S P$ : Superficial lobe delineation (blue line)

\section{MATERIALS AND METHODS}

\section{Patients}

From May 2009 to September 2009, 13 patients with SCCHN were treated with IMRT (Eclipse version 8.1.20) and concomitant weekly chemotherapy. Location of primary cancers were tongue, hypopharynx or nasopharynx. Patient characteristics are summarized in Table 1.

Planning target volume (PTV) of primary nasopharyngial lesion was treated as Table 1 and PTV of metastatic lymph node site or site of close margins to tumor bed were given 66 Gy ( $>95 \%$, priority level 80). Elective lymphatic region was treated with 50 Gy for 4 patients and 54 Gy for 9 patients $(>95 \%)$. Parotid glands (superficial and deep lobes) are delineated and constrained as $20 \mathrm{~Gy}(<10 \%)$ and $26 \mathrm{~Gy}(<1 \%$, priority level 1.1-1.9).

The virtual IMRT plans were done by delineation of superficial lobe of parotid gland only (Figure 1). Delineation of lymphatic region, dose prescriptions and dose constrains were the same as the original IMRT.

\section{Technique}

The dose volume histograms (DVH) of original IMRT and virtual IMRT were assessed for every patient. PTV of lymphatic region is planned for 50 Gy. The lymphatic radiation dose at $95 \%$ volume of PTV of lymphatic region (LW50) was noted when the whole parotid gland was constrained. Additi-

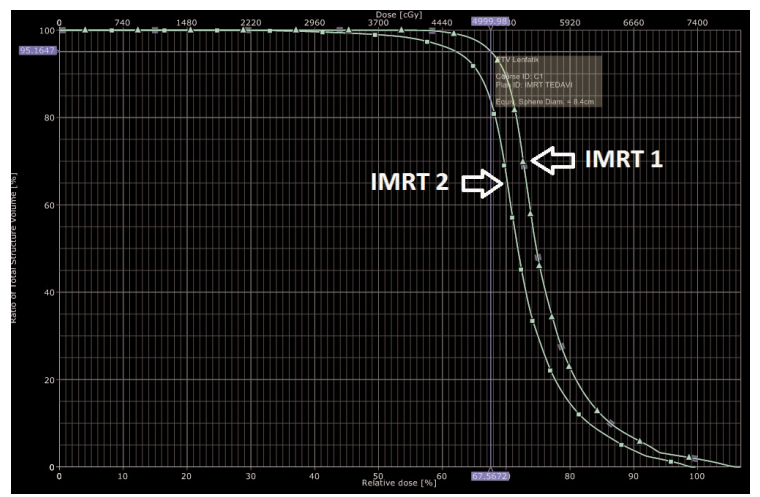

Figure 2. The histograms of IMRT plans and the doses of lymphatic region

IMRT 1: The dose volume graph of lymphatic region in the IMRT with superficial lobe definition only

IMRT 2: The dose volume graph of lymphatic region in the IMRT with whole parotis gland definition 


\begin{tabular}{|c|c|c|c|c|c|}
\hline Pts & Primary tumor & Sex & Age & Fraction Dose & Fraction No \\
\hline 1 & Tongue & M & 68 & 220 & 30 \\
\hline 3 & Tongue & $\mathrm{F}$ & 48 & 200 & 33 \\
\hline 4 & $\mathrm{HP}$ & M & 61 & 200 & 35 \\
\hline 5 & NP & M & 63 & 200 & 37 \\
\hline 6 & NP & $\mathrm{F}$ & 59 & 200 & 37 \\
\hline 7 & $\mathrm{HP}$ & $\mathrm{F}$ & 66 & 220 & 33 \\
\hline 8 & Tongue & $\mathrm{F}$ & 53 & 200 & 33 \\
\hline 9 & NP & M & 21 & 200 & 37 \\
\hline 10 & NP & M & 71 & 200 & 37 \\
\hline 11 & NP & M & 65 & 200 & 37 \\
\hline 12 & NP & $\mathrm{F}$ & 46 & 200 & 37 \\
\hline 13 & NP & M & 44 & 220 & 33 \\
\hline
\end{tabular}

onally, the lymphatic radiation dose at $95 \%$ volume of PTV of lymphatic region (LS50) was noted when the superficial lobe of parotid gland was constrained. Figure 2 shows the histograms of IMRT plans of a patient and the doses of lymphatic regions. If the patient was treated with $54 \mathrm{~Gy}$ for lymphatic region, DVH of IMRT plans were evaluated, and LW54 and LS54 values were noted. The mean values of LW50, LS50, LW54, LS54 were calculated and compared for evaluation.

\section{RESULTS}

When the whole parotid gland was delineated for IMRT plan, the mean dose for lymphatic region was $4733 \mathrm{cGy}$. If the superficial lobe was delineated only, the mean dose for lymphatic region was 5020 cGy. There was no dose change for either PTV for primary lesion nor PTV for metastatic lymph node. The decrease in the dose of lymphatic region was 5.8\% (2.9 Gy) and the dose of superficial lobes of parotid glands more than 30 Gy became $2 \%$. For the patients who received 54 Gy to the lymphatic region, the decrease in dose was $5.8 \%$ (3.1 Gy) and the dose of superficial lobes of paroid glands more than 30 Gy became $4 \%$.

\section{DISCUSSION}

Protecting parotid gland during RT of SCCHN patients is important to avoid hyposalivation and xerostomia. Sparing of the parotid gland could be achieved by using IMRT, comparing with three dimensional conformal RT. ${ }^{9}$ Nevertheless, there are some uncertain points related to volume definition of parotid gland. Firstly, there is no consensus about the cranial border of the RT target volume of the level II neck nodes in the literature. The cranial border of level II is the transverse process of the atlas or at the top of the corpus of the atlas. ${ }^{10,11}$ The dose to the parotid glands depends on the cranial border of the lymph node target volume. Secondly, the parotid gland delineation especially the deep lobe may differ from instution to instution. ${ }^{12}$

The lymphatic region near to deep lobe of parotid gland is affected from this uncertainity. In the literature, recurrent disease of SCCHN patients after IMRT are reported in the region of spared parotid gland. ${ }^{5,6}$ To avoid the recurrences in the neck lymphatic region, the efficient radiation dose should be delivered..$^{13}$ For the high risk lymphatic region, dose escalation is also recommended. ${ }^{7.8} \mathrm{By}$ excluding deep lobe of parotid gland delineation, the decrease of radiation dose of lymphatic region was 
prevented without any change of dose of primary lesion or lymph node. The mean parotid gland from IMRT plans increases slightly and the supeficial lobe which is the major functioning part of parotid gland could be spared. In our dosimetric study, the dose of superficial lobes of parotid gland more than $30 \mathrm{~Gy}$ became $2-4 \%$ when the deep lobe was excluded. On the other hand lymphatic region next to the parotid gland was given radiation without any decrease of dose.

In conclusion, exclusion of sparing of deep lobe of parotid gland prevents decrease of radiation dose in the lymphatic region. It would be a treatment rationale to avoid the dose drop in the metastatic side of the neck region or the site of high risk for recurrence next to the parotid gland.

\section{REFERENCES}

1. Cooper JS, Fu K, Marks J. Late effects of radiation therapy in the head and neck region. Int $\mathrm{J}$ Radiat Oncol Biol Phys 31: 1141-1164, 1995.

2. Nishimura $Y$, Nakamatsu K, Shibata T, et al. Importance of the initial volume of parotid glands in xerostomia for patients with head and neck cancers treated with IMRT. Jpn J Clin Oncol 35: 375-379, 2005.

3. Lin A, Kim HM, Terrell JE, et al. Quality of life after parotid-sparing IMRT for head-and-neck cancer: a prospective longitudinal study. Int J Radiat Oncol Biol Phys 57: 61-70, 2003.

4. Eisbruch A, Ship JA, Martel MK, et al. Parotid gland sparing in patients undergoing bilateral head and neck irradiation: techniques and early results. Int $J$ Radiat Oncol Biol Phys 36: 469-480, 1996.

5. Cannon DM, Lee NY. Recurrence in region of spared parotid gland after definitive intensity-modulated RT for head and neck cancer. Int J Radiat Oncol Biol Phys 70: 660-665, 2008.

6. Lin DS, Jen YM, Lee JC, et al. Recurrence of nasopharyngeal carcinoma in the parotid region after parotid-gland-sparing RT. J Formos Med Assoc110: 655660, 2011.

7. Dawson LA, Anzai Y, Marsh L, et al. Patterns of localregional recurrence following parotid-sparing conformal and segmental intensity-modulated RT for head and neck cancer. Int J Radiat Oncol Biol Phys. 46: 1117-1126, 2000.

8. Chao KS, Ozyigit G, Tran BN, et al. Patterns of failure in patients receiving definitive and postoperative IMRT for head-and-neck cancer. Int J Radiat Oncol Biol Phys 55: 312-321, 2003.
9. Chao KSC, Majhail N, Huang CJ, et al. Intensity-modulated radiation therapy reduces late salivary toxicity without compromising tumor control in patient with oropharyngeal carcinoma: a comparison with onventional techniques. Radiother Oncol 61: 275-280, 2001.

10. Shah JP, Medina JE, Shaha AR, et al. Cervical lymph node metastases. Curr Probl Surg 30: 284-335, 1993.

11. Nowak PJCM, Wijers OB, Lagerwaard FJ, Levendag PC. A three-dimensional CT-based target definition for elective irradiation of the neck. Int $\mathrm{J}$ Radiat Oncol Biol Phys 45: 33-39, 1999.

12. Park SH, Park HC, et al. Multi-institutional comparison of intensity modulated radiation therapy (IMRT) planning strategies and planning results for nasopharyngeal cancer. J Korean Med Sci 24: 248-55, 2009.

13. Tome WA, Hong TS, Gentry LR, et al. Manon Integrity of Parotid Gland Delineation for H\&N IMRT. Int J Radiat Oncol Biol Phy 63: Suppl 1, S130-S131, 2005.

\section{Correspondence}

Dr. Eren ÇETiN

Gazi Üniversitesi Tıp Fakültesi

Radyasyon Onkolojisi Anabilim Dalı

06500

Beşevler, ANKARA / TURKEY

Tel : (+90.312) 2026595

e-mail: erencetin@gazi.edu.tr 